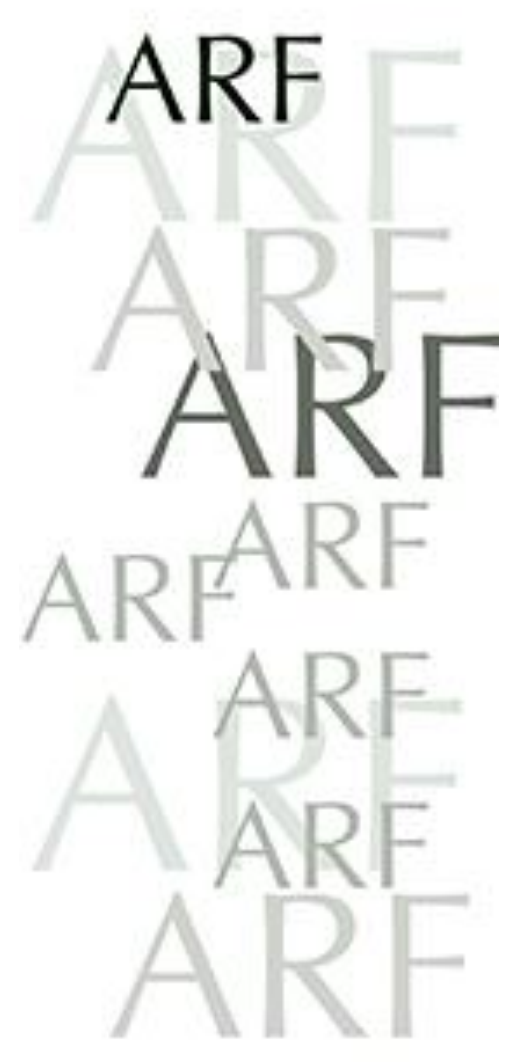

\title{
The Potential Contribution of Wood in Green Building Certifications
}

\author{
Prospects in sustainable residential buildings
}

\author{
Chiara Piccardo \\ Department of Bioproducts and Biosystems, Aalto University \\ chiara.piccardo@aalto.fi
}

\author{
Ashraful Alam \\ Department of Bioproducts and Biosystems, Aalto University \\ ashraful.alam@aalto.fi \\ Mark Hughes \\ Department of Bioproducts and Biosystems, Aalto University \\ mark.hughes@aalto.fi
}

\begin{abstract}
The building sector has a significant impact on the environment, accounting for $36 \%$ of $\mathrm{CO}_{2}$ emissions and about half of material consumption in Europe. Residential buildings dominate the European building stock. In Finland, residential buildings account for up to $80 \%$ of the existing buildings and the rate of construction is higher compared to other building types. Therefore, residential buildings play an important role in the transition to a sustainable built environment. A number of studies show that increasing the use of wood can lower the life cycle environmental impacts of buildings. In Scandinavia, the use of wood in small houses is well established, used in $90 \%$ of cases. Furthermore, the increasing number of high-rise wooden buildings suggests a growing interest in the potential of wood in large-scale buildings. Green building certification provides criteria to assess the sustainability level of buildings and is expected to influence the building sector in the near future, by promoting the use of sustainable technologies. The aim of this study was to investigate how green building certification schemes assess wood materials and how wood materials can help fulfil sustainability criteria for green buildings. We analyse the sustainability criteria adopted by the most common certification schemes in Finland, BREEAM, LEED and the Nordic Swan Ecolabel, as well as the upcoming Level(s) certification promoted by the European Commission. The analysis shows that the contribution of wood materials to the overall score of green building certifications accounts for between 10 and $36 \%$. Wood is advantageous as a renewable and low-carbon material. Furthermore, wood can offer indirect benefits due to its recycling potential and to water saving in the construction stage. However, wood materials have to comply with some requirements, such as sustainable forest management and low volatile organic compound content. The new European certification suggests a comprehensive assessment including circular material life cycles.
\end{abstract}

Keywords: wood materials, green building certifications, sustainability 


\section{Introduction}

\section{Environmental impact of buildings}

The building sector has a significant impact on the environment, accounting for $36 \%$ of final energy use and $39 \%$ of $\mathrm{CO}_{2}$ emissions globally (UN Environment and International Energy Agency, 2017), as well as half of material consumption (European Commission, 2004). Residential buildings are the most relevant building type, accounting for up to $80 \%$ of the European building stock, with significant variations among countries (European Commission, n.d.). In Finland, the share of existing residential buildings is numerically equal to $85 \%$ (Official Statistics of Finland, 2018a) and the rate of new building is higher compared to other building types (Official Statistics of Finland, 2018b). Therefore, residential buildings play a significant role in the transition to a sustainable built environment.

\section{Wood materials can significantly contribute to the sustainability performance of certified residential buildings.}

In the last few years, several studies have investigated the life cycle impact of buildings. The use stage of buildings currently accounts for the highest share of energy and carbon impacts, but this is expected to decrease, due to the implementation of energy efficiency measures. This may result in an increase in the relevance of the other life cycle stages of buildings, especially production (Sartori and Hestnes, 2007; Chastas, et al., 2016; Karimpour, et al., 2014). In the production stage, the selection of building materials can significantly affect the energy and carbon impacts. Therefore, a life cycle approach is important to assess the environmental performance of buildings. Studies from several countries have shown that wood materials used in building frames usually use less energy and release less $\mathrm{CO}_{2}$ than other materials throughout the life cycle (Gustavsson, et al., 2006; Gerilla, et al., 2007; Upton, et al., 2008; Dodoo, et al., 2009; Blengini and Di Carlo, 2010; Bribián, et al., 2011; Nässén, et al., 2012; Tettey, et al., 2014; Peñaloza, et al., 2016; Kovacic, et al., 2018; Pittau, et al., 2018). This is due to the relatively small amount of energy needed to manufacture wood products compared to other materials and the opportunity to replace fossil fuels with wood by-products during the manufacturing process. Furthermore, wood materials temporarily store carbon sequestrated in forest biomass until their combustion or natural decomposition. Some studies have also investigated the potential benefits from the substitution of high-carbon materials with functionally equivalent wood products (i.e. wood substitution). Recently, the European Forest Institute reports an average substitution factor of $1.3 \mathrm{~kg} \mathrm{C} \mathrm{/} \mathrm{kg} \mathrm{C} \mathrm{for} \mathrm{structural}$ materials and $1.6 \mathrm{~kg} \mathrm{C} \mathrm{/} \mathrm{kg} \mathrm{C} \mathrm{for} \mathrm{non-structural} \mathrm{materials} \mathrm{(Leskinen,} \mathrm{et} \mathrm{al.,} \mathrm{2018).}$

\section{Trends in wooden buildings}

In the last decade, the demand for wood products has increased globally (Ramage, et al., 2017) and engineered wood products have become increasingly popular. The production volume of Cross Laminated Timber (CLT) increased 14 times between 2000 and 2015 (Brandner, et al., 2016), while the volume of Laminated Veneer Lumber (LVL) almost doubled in the same period (Hakkarainen, et al., 2019). In particular, the use of wood products has grown in residential buildings. In Scandinavia, the use of wood is well established in small houses (Figure 1), with about $90 \%$ of single-family houses built of the material (Schauerte, 2010), and has recently been increasing in large-scale buildings. In Finland, the share of residential buildings made of wood is $84 \%$, with an increase of $36 \%$ between 1960 and 2017 (Official Statistics of Finland, 2018c). Eighty wooden multi-storey residential buildings were built between 1995 and 2018 (Puuinfo, 2018a), accounting for over $90 \%$ of the total wooden multi-storey buildings and about $5 \%$ of the total multi-storey residential buildings built in the same period, by floor area. The construction of wooden multi-storey residential buildings has also been encouraged by the National Wood Programme, promoted by the Finnish Ministry of Employment and Economy, setting a target of $10 \%$ in the market of mid-rise multi-apartment buildings (Sunabacka, 2015).

The increasing number of large-scale wooden buildings may be attributable to the shift of technical standards (e.g. Eurocode) from a prescription-based design

PEER-REVIEWED ARTICLE 
basis to a performance-based design basis (Ramage, et al., 2017). For example, in Finland, changes in fire regulations have allowed the use of wood in building frames and façades up to four storeys since 1997, and up to eight storeys since 2011 under standardized conditions (Puuinfo, 2018b), while the eight-storey limit does not apply in the case of individual fire performance analysis. Furthermore, the increasing use of wood in buildings may be encouraged by new environmental policies for the built environment. For example, some cities with carbon neutrality objectives (e.g. Copenhagen, Helsinki, Seattle and Vancouver) support the use of wood as a building material or as fuel. Helsinki municipality has recently made the use of wood materials in the new buildings of Honkasuo district mandatory. This decision was legitimized by the Finnish Supreme Court in 2015 based on the Land Use and Building Act 132/1999 of the Ministry of the Environment, which allows municipalities to supervise and approve plans and projects, including the possibility to introduce design constraints (e.g. the use of specific materials) in urban regulations (Franzini, et al., 2018). However, to underpin the role of wood products in sustainable buildings, there is a need to increase debate (amongst stakeholders) so as to inform future practices and policies in the building sector.

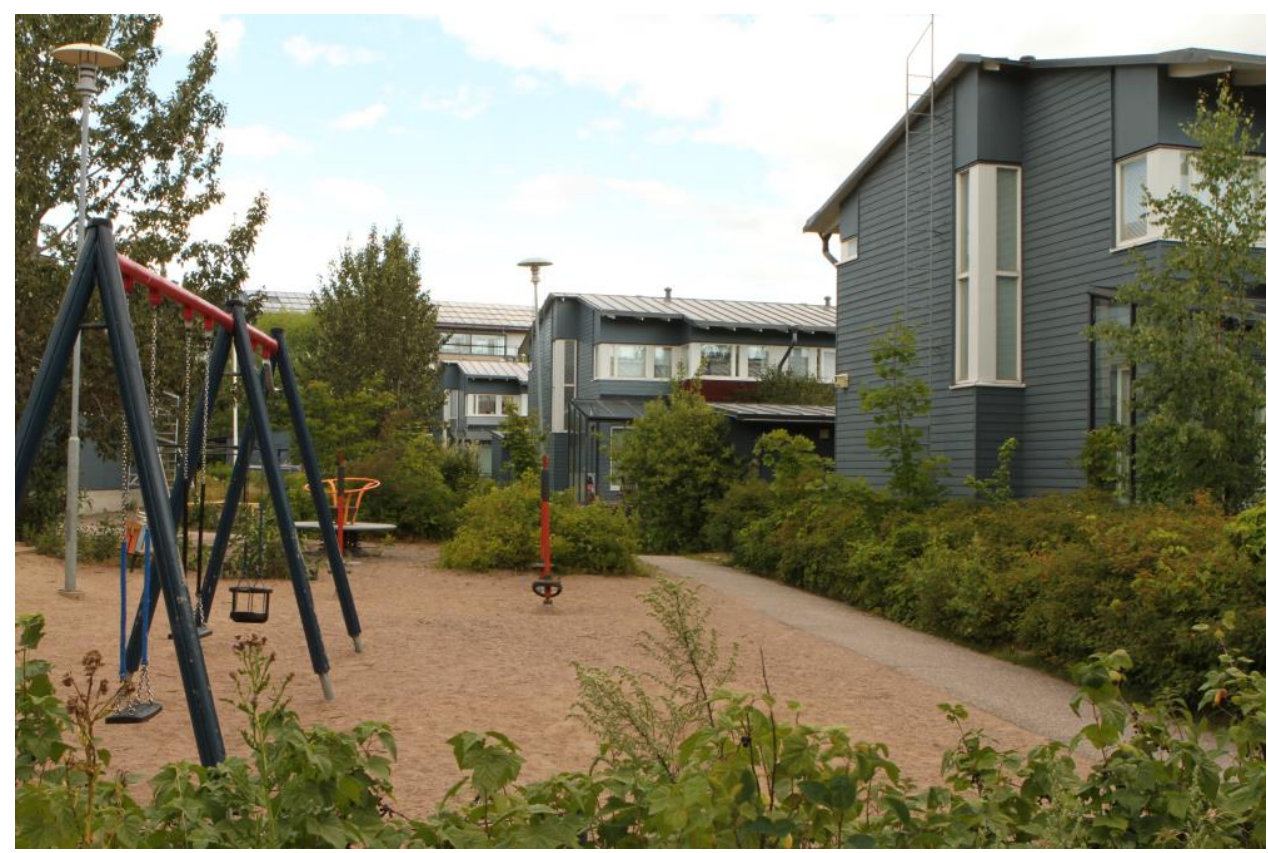

Figure 1. Wooden houses in Viikki eco-district in Helsinki (photo by C. Piccardo).

\section{Green building certifications}

Although a number of studies shows that wood has higher environmental performance compared to other building materials, the use of wood for environmental purposes is not regulated by current building codes and technical standards. Nonetheless, voluntary standards, such as green building certification schemes, can be used to evaluate the potential of wood in sustainable buildings.

Green building certifications have gained global prominence due to the recent calls for increasing the sustainability performance of the built environment. In Europe in particular, the demand for green building certifications has increased in the last five years (Porumb, et al., 2020), and is expected to increase further in the near future (Dodge Data \& Analytics, 2018). Green building certification schemes provide comprehensive assessment methods, including environmental, economic, social, and health aspects. Each green building certification scheme consists of check-list of sustainability criteria. The assessment process is usually based on a rating system that assigns a number of points to each sustainability criterion, depending on the performance level of the building. Green building 
certifications usually result in a sustainability label with a final score that enables the performance of the building to be communicated to a large audience.

Green building certifications have received increasing attention from the scientific community over the past ten years (Li, et al., 2020). Several studies have compared different certification schemes to provide an insight into the assessment of green buildings in terms of categories, criteria and indicators ( $\mathrm{Li}$, et al., 2017). Säynäjoki, et al. (2012) compared sustainability assessment methods at the district and urban scale to understand how they respond to urban development projects in Finland, using a review of the literature and grounded theory. Saraiva Freitas and Zhang (2018) compared the most commonly used green building certification schemes in Sweden according to the SWOT method, in order to inform the choice of certification schemes based on the project purpose. Suzer (2019) compared LEED and BREEAM certification schemes by assessing different case-study projects, in order to examine the compliance and correlation between the two rating systems. However, the majority of the comparative studies focused on the general assessment methodology and its compliance with different project types. A few studies have analysed the assessment method for building materials in existing green building certification schemes. Zubizarreta, et al. (2019) stated that a few studies consider the sustainability assessment of a specific part of the buildings and reviewed several existing green building certification schemes to develop a new assessment method for timber structures. Cobut, et al. (2013) analysed the potential of wellknown environmental labels for wood products to reduce the environmental impact of non-residential buildings, combining grounded theory and life cycle thinking. However, the potential of using wood in certified green buildings needs to be investigated further.

\section{Aim of the study}

This study analyses the potential contribution that wood products can make to increase the sustainability performance of certified buildings, taking into account the most commonly used and well-known green building certification schemes in Finland. The study focuses on residential buildings, which represent a relevant building type in the Finnish building stock and within existing wooden buildings. The study also discusses the effectiveness of the certification categories and criteria to assess a sustainable use of wood materials.

\section{Methodology}

\section{General approach}

Our methodological approach consists of three steps, as described below.

- First, we review green building certification schemes based on publicly available data, such as certification guidelines and standards, in order to define rating systems, categories and criteria. Following an iterative process, we also analyse the categories and criteria of different certification schemes to identify the key sustainability requirements to which wood materials can contribute (Figure 2). Only the categories and criteria concerning the key sustainability requirements will be considered in the following steps.

- Second, we estimate the contribution of wood materials for each key sustainability requirement in terms of potential score achievable in the green building certifications. In order to make the scores comparable between different certification schemes, we calculate the ratio between the potential score achievable with the use of wood and the maximum score of the certification scheme.

- Third, we perform a critical analysis of the green building certification schemes using a life cycle thinking approach, based on Cobut, et al. (2013). The content of the categories and criteria is evaluated according to a life cycle perspective. This allows an evaluation of the effectiveness of green building certification schemes to assess a sustainable use of wood materials in buildings. 


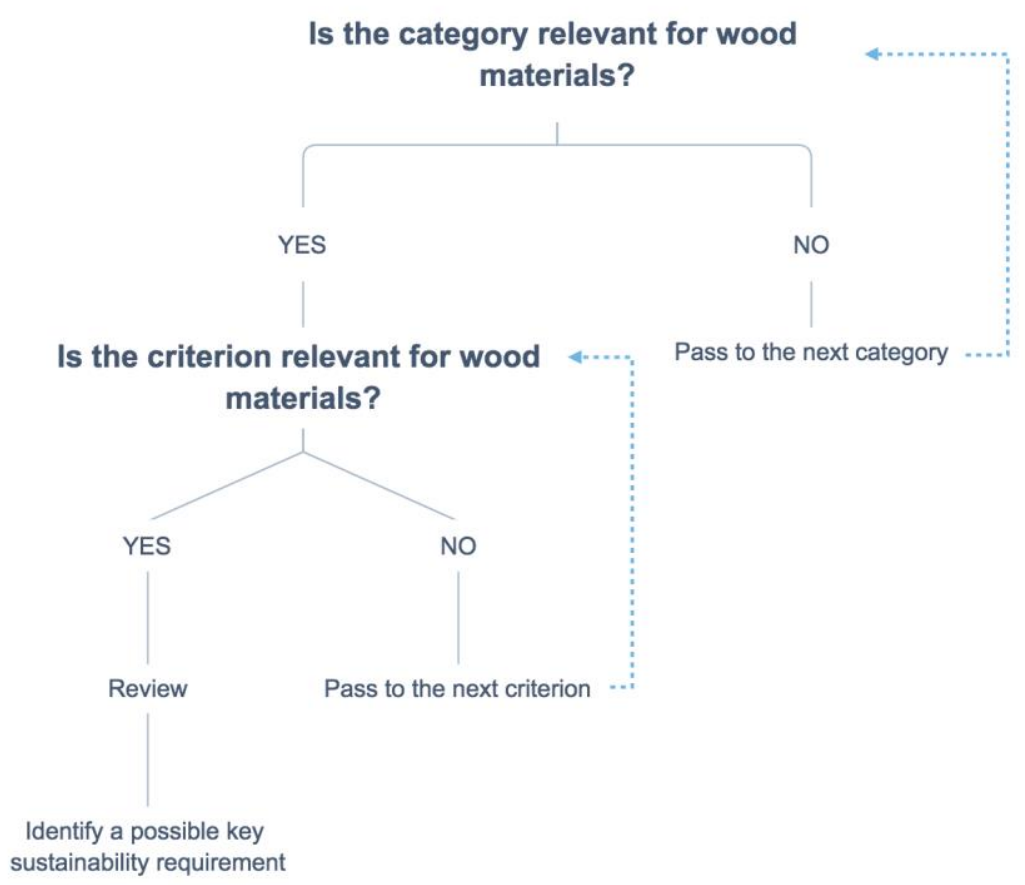

Figure 2. Iterative process for the analysis of assessment categories and criteria

The green building certification schemes analysed

The most commonly used and well-known certification schemes in Finland BREEAM, LEED and the Nordic Swan Ecolabel - are analysed, as well as the Level(s) certification framework, recently promoted by the European Commission (Table 1). BREEAM (Building Research Establishment's Environmental Assessment Method), launched in 1990, is an international green building certification scheme promoted by the British organization BRE (Building Research Establishment). The BREEAM rating system comprises ten sustainability categories, plus an additional category on innovation, which are assigned a number of points and a weighting factor. Furthermore, for each country, BRE reviews the weighting factors of those categories affected by local conditions in order to provide a more appropriate rating system. BREEAM provides four alternative rating levels declared in the BREEAM certificate. LEED (Leadership in Energy in Environmental Design), launched in 1998, is promoted by the U.S. Green Building Council (USGBC) and is today applied in several countries. The LEED rating system is composed of nine sustainability categories including a final category on regional priorities that gives the opportunity to increase the points of those categories addressing local issues. LEED provides four rating levels identified by different labels. The Nordic Swan Ecolabel is a certification scheme applied in the Nordic countries (i.e. Denmark, Finland, Iceland, Norway and Sweden), covering different product categories, including residential and school buildings. In contrast to BREEAM and LEED, the Nordic Swan rating system for buildings is divided into seven compulsory categories and fourteen point-scoring categories. The Nordic Swan Ecolabel is awarded if the compulsory requirements are fulfilled and a minimum number of points achieved. The common aim of the BREEAM, LEED and Nordic Swan Ecolabel programmes analysed is to increase the environmental performance of residential buildings in terms of land use, water management, energy and resource efficiency. All the programmes also include categories affecting the social and economic sustainability of buildings (e.g. design management, indoor environment, innovation). The Nordic Swan Ecolabel, in particular, pays specific attention to the health of the indoor environment. 
Finally, Level(s) is a certification framework promoted by the European Commission in order to encourage a life cycle approach in the environmental assessment of buildings. The objective of Level(s) is to provide a common framework to assess green buildings and to integrate existing standards into a single protocol. The certification protocol has been tested in different European countries, including Finland, and will be officially launched in 2020. Existing green building certification schemes applied in Europe should align to the Level(s) certification framework in order to provide comparable data on the environmental performance of buildings. Compared to the other certification schemes, Level(s) does not provide a rating system but rather methodological guidelines for the assessment process. Furthermore, Level(s) does not provide prescriptive requirements but focuses on six environmental impact indicators through the entire life cycle of the building (i.e. greenhouse gas emissions, resource efficiency, water use, health and comfort, resilience and adaptation to climate change, and cost and value). It also provides tools supporting the assessment of different environmental impacts.

Table 1. General information of the analysed green building certifications.

\begin{tabular}{|c|c|c|c|c|}
\hline & BREEAM & LEED & $\begin{array}{l}\text { Nordic Swan } \\
\text { Ecolabel }\end{array}$ & Level(s) \\
\hline Scheme name & $\begin{array}{l}\text { BREEAM } \\
\text { International New } \\
\text { Construction } 2016\end{array}$ & $\begin{array}{l}\text { LEED v4 for } \\
\text { Homes Design } \\
\text { and Construction }\end{array}$ & $\begin{array}{l}\text { Nordic Ecolabelling } \\
\text { for Small houses, } \\
\text { apartment buildings } \\
\text { and buildings for } \\
\text { schools and pre- } \\
\text { schools }\end{array}$ & Level(s) \\
\hline Institution & BRE Global & $\begin{array}{l}\text { Green Building } \\
\text { Council }\end{array}$ & $\begin{array}{l}\text { Nordic Council of } \\
\text { Ministers }\end{array}$ & $\begin{array}{l}\text { European } \\
\text { Commission }\end{array}$ \\
\hline $\begin{array}{l}\text { Geographical } \\
\text { scope }\end{array}$ & International & International & Nordic countries & Europe \\
\hline Last update & 2016 & 2014 & 2016 & 2018 \\
\hline References & BREEAM, 2016 & LEED, 2013 & $\begin{array}{l}\text { Nordic Swan } \\
\text { Ecolabel, } 2016\end{array}$ & $\begin{array}{l}\text { European } \\
\text { Commission, } \\
2017 a \text { and } \\
2017 b\end{array}$ \\
\hline
\end{tabular}

\section{Results and discussion}

\section{Review of certification schemes analysed}

Table 2 shows the sustainability categories of the certification schemes analysed that contain relevant criteria for the use of wood materials. The review of these categories and criteria has shown that wood materials in green building certifications can mainly contribute to four key sustainability requirements: material supply sustainability, indoor air quality, waste management efficiency, and resource-oriented design.

Table 2. Categories of the certification schemes analysed relevant for wood materials.

\begin{tabular}{|c|c|c|c|}
\hline BREEAM & LEED & Nordic Swan Ecolabel & Level(s) \\
\hline $\begin{array}{l}\text { - Health and wellbeing } \\
\text {-Materials } \\
\text {-Waste }\end{array}$ & $\begin{array}{l}\text {-Materials and } \\
\text { resources } \\
\text { - Indoor environmental } \\
\text { quality }\end{array}$ & $\begin{array}{l}\text {-Timber structures } \\
\text {-Ecolabelled } \\
\text { construction products } \\
\text {-Wooden mouldings } \\
\text { from certified forestry } \\
\text {-Recycled or reused } \\
\text { materials in }[. . .] \\
\text { products } \\
\text {-Recycling of }[\ldots] \text { waste }\end{array}$ & $\begin{array}{l}\text {-Greenhouse gas } \\
\text { emissions along a } \\
\text { buildings' life cycle } \\
\text { - Resource efficient } \\
\text { and circular material } \\
\text { life cycles } \\
\text { - Healthy and } \\
\text { comfortable spaces } \\
\text {-Optimised life cycle } \\
\text { cost and value }\end{array}$ \\
\hline
\end{tabular}

The only categories relevant for wood materials are listed. In BREEAM, LEED and Nordic Swan Ecolabel, the only point-score categories are mentioned. 


\section{Material supply sustainability}

This key sustainability requirement includes criteria rewarding the sustainable supply of building materials, including their manufacturing process (Table $3 a$ ).

According to BREEAM, LEED and Nordic Swan Ecolabel, wood from sustainable forest management is a required attribute. This criterion specifically encourages the procurement of responsibly sourced wood materials, preventing related environmental and social burdens from illegal forest management. Wood materials should be certified by internationally recognised forest management certification schemes, such as FSC (Forest Stewardship Council) or PEFC (Programme for the Endorsement of Forest Certification), or other third party approved certification schemes. LEED and Nordic Swan Ecolabel also prohibit specific wood species, especially from tropical regions. Additionally, some certification schemes give extra points based on the amount of certified wood. BREEAM gives points if the design stage includes a detailed sustainable procurement plan, and if at least $10 \%$ of building materials by volume or mass can be proven to be responsibly sourced. In the second case, wood materials can contribute to the scoring as much as the use of wood is increased (for example, if wood materials are used in structural elements). Nordic Swan Ecolabel gives points if at least $50 \%$ of the wood materials used in decorative elements are certified. However, all the certification schemes propose the use of reused or recycled wood materials, without any restriction about the origin, instead of new wood materials with sustainable forest management certification. This condition might encourage the use of reused or recycled wood products. LEED gives points if the building materials are extracted, processed, and manufactured locally, assuming a minimum haul distance of $160 \mathrm{~km}$ and prescribing specific building elements (i.e. framing, aggregate for concrete and foundation, drywall or interior sheathing). Wood materials contribute to the scoring depending on their origin and supply chain. Finally, since Level(s) is based on life cycle environmental indicators, the sustainability of forest management for wood materials is not explicitly assessed. However, Level(s) invites consideration of the limitations of life cycle analysis (LCA) as a tool.

Table 3a. Summary of the criteria concerning the material supply sustainability.

\begin{tabular}{lcccc}
\hline & BREEAM & LEED & Nordic Swan Ecolabel & Level(s) \\
\hline Sustainable forest management & $\checkmark$ & $\checkmark$ & $\checkmark$ & \\
Avoidance of tropical wood & & $\checkmark$ & $\checkmark$ & \\
Local production & & $\checkmark$ & $\checkmark$ & $\checkmark$ \\
Environmentally certified products & $\checkmark$ & & \\
Use of local wood & & $\checkmark$ & \\
Use of bio-based materials & & $\checkmark$ & \\
Extended producer responsibility & & & \\
Calculation of the GWP indicator & &
\end{tabular}

Other relevant criteria for the sustainability of material supply concern the life cycle environmental impact of building materials. BREEAM, LEED and Nordic Swan Ecolabel recognise a number of points when a sufficient quantity of materials used in the building shows low environmental impact. However, the criteria used to reward the use of such materials vary significantly between different certification schemes. BREEAM and the Nordic Swan Ecolabel criteria suggest the use of materials certified with Environmental Product Declarations (EPDs) and the Nordic Swan/EU Ecolabel, respectively. LEED provides alternative requirements (e.g. content of reused/recycled materials; the use of 
bio-based materials from sustainable agriculture; subscription to an extended responsibility program), increasing the minimum quantity of materials needed to fulfil the criterion. The Nordic Swan Ecolabel is the only certification scheme rewarding the use of renewable materials, specifically in the structure and/or façade (if at least $50 \%$ by area is maintenance-free). Finally, Level(s) recommends using the Global Warming Potential (GWP) indicator $\left(\mathrm{kg} \mathrm{CO}_{2}\right.$ $\mathrm{eq} / \mathrm{m}^{2} /$ year) to calculate the life cycle environmental impact of building materials. The GWP should be calculated for each life cycle stage of the building, including the production stage, which is highly relevant for building materials. Potential trade-offs between the production and use stages should be also considered in order to minimise the total greenhouse gas emissions. However, as well as the other certification schemes, Level(s) does not provide any benchmark for a low environmental impact of building materials.

\section{Indoor air quality}

This key sustainability requirement includes criteria rewarding the use of nonhazardous materials, or the reduction of chemical substances potentially harmful for people, in the indoor environment (Table 3b).

BREEAM, LEED and Nordic Swan Ecolabel criteria encourage the improvement of indoor air quality from the design stage. All the certification schemes require limits to volatile organic compounds (VOCs) emissions from resins, adhesive and coatings in wood products used in the indoor environment (e.g. wood particleboard, wood flooring and fittings). However, the emission limits vary between the certification schemes. BREEAM gives points if an indoor air quality plan is produced and implemented, as well as if the formaldehyde emission from a number of products, including wood-based products, does not exceed 0.06 $\mathrm{mg} / \mathrm{m}^{3}$. Furthermore, an additional point is given if the post-construction formaldehyde and total VOCs concentrations in indoor air does not exceed 100 $\mathrm{mg} / \mathrm{m}^{3}$ and $300 \mathrm{mg} / \mathrm{m}^{3}$ on average, respectively. LEED gives points if at least $90 \%$ of the wood-based materials by building element (e.g. flooring and insulation) complies with the California Air Resources Board (CARB) requirements for ultra-low-emitting formaldehyde (ULEF) resins, which are 0.05 ppm for particleboards and $0.06 \mathrm{ppm}$ for medium density fibreboard (MDF). The Nordic Swan Ecolabel provides a compulsory category, setting an average formaldehyde emission of a maximum of $0.124 \mathrm{mg} / \mathrm{m}^{3}$ air for MDF panels and $0.07 \mathrm{mg} / \mathrm{m}^{3}$ air for all other types of panel or, alternatively, an internationally recognised certification. Furthermore, the Nordic Swan Ecolabel also prescribes the avoidance of chemical substances that are carcinogenic, mutagenic or toxic for reproduction, as well as other potentially hazardous substances included in the European Chemicals Agency (ECHA)'s Candidate List.

Level(s) provides an indicator on indoor air quality, including the effects of pollutants from building materials, such as carcinogenic VOCs, formaldehyde and mould. The determination of emissions from building materials should comply with CEN/TS 16516 standard and should be performed on the as-finished product. This recommendation is important because, although the standard EN $13986+\mathrm{A} 1$ (2015) harmonizes the performance characteristics of wood-based panels, including a maximum level of formaldehyde emissions $\left(0.124 \mathrm{mg} / \mathrm{m}^{3}\right.$ in the air of a test chamber used under the conditions prescribed in the European Standard EN 717-1), and in the last few years European manufacturers have taken appropriate measures to comply with this standard, meeting this performance level is not compulsory. The determination of mould has no specific standards, but Level(s) provides guidance on testing and inspection. Here, wood particleboard and floor coverings are mentioned as target materials. 
Table 3b. Summary of the criteria concerning the indoor air quality.

\begin{tabular}{lcccc}
\hline & BREEAM & LEED & Nordic Swan Ecolabel & Level(s) \\
\hline $\begin{array}{l}\text { Indoor air quality plan } \\
\text { Limited VOCs emissions from wood } \\
\text { products }\end{array}$ & $\checkmark$ & $\checkmark$ & $\checkmark$ \\
$\begin{array}{l}\text { Avoidance of recognised/potentially } \\
\text { hazardous chemical substances }\end{array}$ & & $\checkmark$ & $\checkmark$ \\
\hline The only criteria relevant for wood materials are listed. & & \\
\hline
\end{tabular}

\section{Waste management efficiency}

This key sustainability requirement includes criteria rewarding an efficient management of construction waste, including sorting, reuse and recycling of building materials (Table $3 \mathrm{c}$ ).

BREEAM gives points if at least $60 \%$ (or the national target share, increased by $10 \%$ ) of construction waste, including wood waste, is diverted from landfill. LEED provides a similar requirement but the reduction of landfilled waste is calculated based on the floor area of the building and excludes incinerated waste. Finally, the Nordic Swan Ecolabel gives points if at least $25 \%$ of construction waste from the building envelope is recycled or reused (excluding wooden fibre products or other wood products made of recycled materials). Furthermore, additional points are given if at least $50 \%$ of the overall construction waste is recycled or reused (incineration is not mentioned). However, all the certification schemes only take into account construction waste, and not demolition waste.

The Level(s) certification framework complies with the Europe Directive $2008 / 98 / E C$, which sets a target of $70 \%$ by weight for the recovery of construction and demolition waste by 2020 , and only considers the reduction of waste through material recovery (i.e. reuse, recycling and backfilling), excluding energy recovery. Furthermore, Level(s) suggests a life cycle assessment through two environmental indicators, GWP and construction and demolition (C\&D) waste. As mentioned, the GWP indicator focuses on greenhouse gas emissions from each life cycle stage of building materials, including the end-of-life stage and the potential benefits and loads beyond the end-of-life. Hence, the assumed end-oflife options of building materials could affect this indicator. The construction and demolition waste indicator $\left(\mathrm{kg}\right.$ waste $\left./ \mathrm{m}^{2}\right)$ focuses on the quantity of waste generated throughout the life cycle of the building, as well as on the type of waste fractions. Compared to the other certification schemes, this indicator introduces a new approach, not only based on the construction stage, but also including the maintenance and end-of-life stages of the building, based on the definition of future scenarios for the building (e.g. expected service life and maintenance measures). The construction and demolition waste indicator takes into account both construction and demolition waste, distinguishing between waste disposed to landfill and by incineration, and waste recovered for reuse, recycling or other material recovery operations (e.g. backfilling).

Although the certification schemes reviewed do not set any specific requirement for wood waste, this environmental issue concerns wood materials significantly. In Finland, wood waste accounts for $41 \%$ of construction and demolition waste (DG ENV European Commission, 2013). This fraction is almost completely delivered to energy plants (Salmenperä, et al., 2015), but could significantly increase the overall rate of recycled and recovered waste (Dahlbo, et al., 2015). Furthermore, as wood is, and will continue to be, a common building material in Finland, the high-grade recycling of wood materials should be encouraged (Laaksonen, et al., 2017). The reuse of some wood elements, such as wood beams, might also become more relevant in the future (Laaksonen, et al., 2017). 
Table 3c. Summary of the criteria concerning the waste management efficiency.

\begin{tabular}{|c|c|c|c|c|}
\hline & BREEAM & LEED & Nordic Swan Ecolabel & Level(s) \\
\hline Reduced construction waste to landfill & $\bar{\checkmark}$ & $\sqrt{ }$ & & \\
\hline Recycled/reused construction waste & & & $\checkmark$ & \\
\hline Calculation of GWP & & & & $\checkmark$ \\
\hline Calculation of C\&D waste & & & & $\checkmark$ \\
\hline
\end{tabular}

\section{Resource-oriented design}

This key sustainability requirement includes criteria rewarding the development of design strategies to facilitate the durability and deconstruction of building parts, as well as the adaptability of the overall building, in order to reduce maintenance operations and waste generation (Table 3d). Therefore, in contrast to the other strategic categories, this category does not concern the wood material itself but rather the approach used to design wooden building parts efficiently. For example, this category might advantage construction systems that do not use cement or adhesive for connections but rather metal connections or other joints with good reversibility, such as some types of wooden construction systems.

Most of the criteria reviewed aim at prolonging the service life of exposed building parts, as well as optimizing the efficient use of materials. BREEAM gives a point if the relevant parts of the building are designed to avoid or limit material degradation due to environmental factors. Furthermore, an additional point is given if resource efficiency measures are undertaken over the life cycle of the building. For instance, this includes using fewer materials, reusing materials from existing buildings, facilitating the replacement of worn-out materials, procuring materials with higher levels of recycled content, and adopting off-site manufacture. LEED gives a point if measures are adopted to increase the durability of the building according to the ENERGY STAR checklist for residential buildings. This includes measures to avoid water and moisture issues during the construction and the use stages of the building. Furthermore, LEED recognises a resource-efficient design applied to at least $90 \%$ of each category of structural elements. This includes simplifying the structural framework, installing structural insulated panels for walls, and using a minimum space of $400 \mathrm{~mm}$ for wall studs, floor joists and roof rafters. The Nordic Swan Ecolabel forbids the use of wood materials impregnated with heavy metals and/or biocides in the outdoor environment, with the exception of elements in direct contact with the ground and in load bearing structures. This should encourage appropriate design of exposed wooden elements to improve durability against weather cycles and biological attack. Finally, the Level(s) framework provides tools and guidance for describing and assessing the design optimization of a building for greater resource efficiency, including potential adaptability and deconstruction of the building. Furthermore, Level(s) also suggests estimating the efficiency of these measures through an indicator on life cycle costs $\left(€ / \mathrm{m}^{2} /\right.$ year $)$.

This strategic category is strictly related to the previous category, waste management efficiency, and is important to improve the sustainable use of wood materials. The certification schemes mainly provide recommendations to increase the durability of building materials, especially for outdoor use. However, a material investigation by Gorgolewski (2018) showed that wood has the most reuse potential compared to other traditional materials, such as concrete, brick and glass. Furthermore, coupling bio-based materials (bio-economy) and circular economy principles appears to be an effective strategy to lower the environmental impacts of the built environment (Corrado and Sala, 2018). According to bio- and circular economy principles, keeping bio-based materials within the technosphere could answer to both climate change mitigation and resource efficiency, for example prolonging the carbon storage in the biomass 
and offsetting the increasing demand of bio-based products and forest resources. Finally, the design improvement of wooden building parts is important to avoid outdoor weathering or other physical and chemical degradations, as well as to reduce the use of chemicals that could be disadvantageous according to environmental certification schemes (e.g. Nordic Swan Ecolabel for both residential buildings and products).

Table 3d. Summary of the criteria concerning the resource-oriented design.

\begin{tabular}{lcccc}
\hline & BREEAM & LEED & Nordic Swan Ecolabel & Level(s) \\
\hline $\begin{array}{l}\text { Improved durability of the } \\
\text { building/building parts }\end{array}$ & $\checkmark$ & $\checkmark$ & \\
Reduced use of materials \\
$\begin{array}{l}\text { Use of durable wood without } \\
\text { impregnation }\end{array}$
\end{tabular}

\section{An estimation of the potential contribution of wood}

The objective of this estimation is not to calculate a realistic score but rather to weight the contribution of wood materials to the overall score of the certification schemes analysed, in terms of percentage value. For each green building certification, we calculated the ratio between the potential score due to the use of wood materials, theoretically, and the maximum score of the certification scheme. To facilitate the comparison between different certification schemes, the contribution of wood materials was calculated based on the four key sustainability requirements: material supply sustainability, indoor air quality, waste management efficiency, and resource-oriented design. Level(s) is not considered because it does not provide a rating system and does not assign points to the environmental indicators. Estimating the potential contribution of wood materials in different certification schemes has shown that wood products can provide:

- direct contributions, linked to the environmental characteristics of wood as a material (e.g. renewable resource);

- indirect contributions, linked to the design and technical characteristics of wooden construction systems rather than the material itself (e.g. possibility to prefabricate building elements, and use of reversible joints).

Furthermore, wood materials can be required to satisfy compulsory sustainability criteria or to comply with specific standards (e.g. sustainable forest management and low emissions of VOCs).

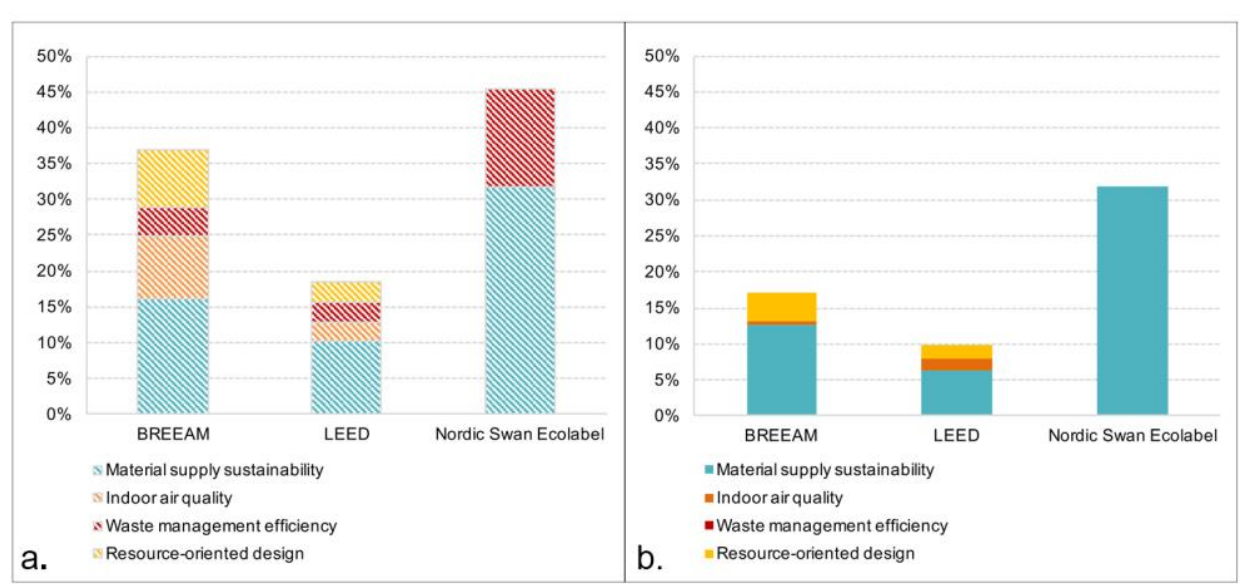

Figure 3. a) Total contribution of the point-score criteria relevant for wood materials to the maximum score achievable with the certification schemes analysed, ordered by key sustainability requirement. b) Potential contribution of wood materials in the relevant pointscore criteria to the maximum score achievable with the certification schemes analysed. 
Figure $3 a$ shows that the criteria relevant for wood materials account for between 18 and $45 \%$ of the maximum score achievable with the certification schemes analysed. In the Nordic Swan Ecolabel, two key sustainability requirements, indoor air quality and resource-oriented design, are not shown because they only include compulsory criteria, which must be fulfilled to obtain the certification and do not contribute to the final score of the certification scheme. Figure $3 b$ shows that the potential contribution of wood materials to the maximum score achievable with the certification schemes analysed accounts for between 10 and $32 \%$. The material supply sustainability represents a key sustainability requirement for wood materials in all the green building certification schemes. Wood is especially advantageous as a renewable and low energy and low carbon material. The indoor air quality is strategic in BREEAM and LEED, accounting for 2 and $18 \%$, respectively, of the total contribution from wood materials. In the waste management efficiency, wood materials could also contribute to the final score depending on the quantity of wood waste from construction activities. However, the certification schemes analysed provide only general criteria on construction waste, without any specific recommendation on wood waste. Hence, the present study cannot estimate the contribution of wood materials to this key sustainability requirement, and a case-by-case estimation should be performed.

\section{Critical analysis through life cycle thinking}

The aim of Life Cycle Thinking (LCT) is to avoid shifting the environmental burden from one stage of the life cycle to another (Pajula, et al., 2017). This is possible if the environmental impacts in the earlier stage of the life cycle are minimized and do not cause additional impacts elsewhere. Indeed, the impacts of a specific value chain can have an effect on a larger scale. Furthermore, LCT is strongly promoted by the new Level(s) certification, which should provide a reference framework for all the other green building certification schemes in Europe in the coming years. Therefore, it is important to apply a life cycle perspective to analyse the effectiveness of green building certification schemes for wood materials.

The life cycle of buildings consists of four main stages: production, construction, use, and end of life (EN 15978, 2011). An additional stage concerning the benefits and loads beyond the end-of-life stage (e.g. energy recovery, recycling or reuse of construction and demolition waste) can be included. This section aims at identifying which stages are included in the reviewed certification schemes, considering strategic categories for wood products.

\section{Production and construction stage}

In the production stage, the key sustainability requirement 'Material supply sustainability' covers most of the environmental issues. The certification schemes analysed show great interest in the sustainable supply of wood materials, especially the harvesting phase of the raw materials. Only LEED considers the haul distance between the manufacturing and construction sites, rewarding locally supplied materials. LEED also recognises the optimization of resource use in structural elements by ensuring the same structural performance with a lower quantity of materials. Furthermore, the certification schemes analysed take into account the use of building materials with low environmental impact, mainly recommending the use of products certified with EPDs or the Nordic Swan/EU Ecolabel. Level(s) mainly covers this life cycle stage through the GWP indicator. However, some issues are highlighted. First, environmental certifications of products are based on different standard and different methodological approach. For example, EPDs are based on the LCA approach, while the EU and Nordic Swan ecolabels are based on a multi-criteria assessment approach. Therefore, the environmental data provided are not comparable. Second, environmental certification of products may not provide all the necessary environmental information. For example, EPDs certify environmental data but do not necessarily prove the good environmental performance of building materials. Multi-criteria environmental certifications for wood products, including the EU and Nordic Swan ecolabels, focus only on specific environmental indicators (e.g. energy use during 
the manufacturing stage) and life cycle stages (e.g. production stage). Third, the EU and Nordic Ecolabel only certify a limited number of product categories, hence only a few wood products (i.e. wood flooring, cladding and windows) are included. This could disadvantage the use of wood materials in those product categories not covered by ecolabels.

In the construction stage, the certification schemes do not give specific requirements, but off-site manufacture is mentioned by BREEAM in order to optimize the resource use. As for the production stage, Level(s) mainly covers this stage through the life cycle GWP indicator.

\section{Use stage}

The use stage is mainly covered by the 'Indoor air quality' strategic category. The certification schemes analysed provide requirements for wood products including resins, adhesives and coatings in wood particleboard, which might affect the air quality of the living spaces. The emission of volatile organic compounds (VOCs), including formaldehyde, are limited according to different standards. Additionally, BREEAM and LEED provide criteria aimed at increasing the durability of building parts. Furthermore, LEED and Nordic Swan specifically mention wooden building parts. This could have effects on the maintenance stage, included in the use stage of the building. The Level(s) indicator on indoor air quality is consistent with the certification schemes mentioned.

\section{End-of-life stage}

In the end-of-life stage, the certification schemes mainly provide criteria encouraging good practices for waste management, such as sorting and, if possible, the recycling and reuse of construction waste. Wood waste is not specifically mentioned by the criteria, but it can contribute significantly to achieving the overall targets for the reuse and recycling of construction waste. The energy recovery of construction waste is included in good practices by BREEAM, excluded by LEED and Level(s), and not clearly stated by Nordic Swan. Design for Disassembly, or any other design strategy facilitating the reuse or recycling of building materials in future, is not mentioned, perhaps due to difficulties in assessing its long-term effectiveness. Only Level(s) suggests the definition of future scenarios to estimate the waste generated in the end-of-life stage of the building, as well as to assess the design optimization for adaptability and deconstruction of building parts.

\section{Conclusions}

The aim of this paper was to review the assessment method for wood materials in existing green building certifications, as well as to evaluate the efficiency of sustainability criteria to increase the sustainable use of wood materials in residential buildings. Through a comparative method, we have identified four key sustainability requirements - material supply sustainability, indoor air quality, waste management efficiency, and resource-oriented design. Then, we undertook qualitative and quantitative analysis to understand the potential of wood materials and the efficiency of environmental criteria, respectively.

The review of certification schemes, as well as the estimation of the potential contribution of wood materials, shows that the use of wood can significantly contribute to the environmental performance of certified residential buildings, by up to $36 \%$ of the total score, theoretically. This is mainly due to the high environmental performance level achievable by wood products, as recognised by the literature, and to the rewards for sustainable forest management and the processing of wood resources. However, consistent with Cobut, et al. (2013), we observe that green building certifications tends to lag behind research findings. According to the literature, wood materials show low energy and carbon impacts throughout their life cycle, compared to other functionally equivalent building materials. However, the potential energy and carbon benefits from the use of wood materials can only marginally influence the total score of certification 
schemes. Takano, et al. (2014) show that the environmental performance of buildings is influenced by the material choice, especially regarding building structures. However, only the Nordic Swan Ecolabel rewards the use of wood materials in relevant building parts, such as structures and façades. Furthermore, the existing certification schemes do not show appropriate criteria to analyse the carbon impacts of building materials, although the potential carbon benefits of wood materials are already recognised by the literature (e.g. IPCC report in 2007). The analysis of the overall environmental impact of materials is almost completely based on the use of environmentally-certified products. Therefore, it is difficult to compare the actual environmental performance level of materials used in green buildings certified with different certification schemes. Finally, certification schemes do not recommend specific indicators or benchmarks to assess the environmental performance of materials. In this case, the LCA approach suggested by the Level(s) framework might encourage a more comprehensive analysis of the environmental impacts of building materials, as well as of wood materials, by green building certification schemes.

Although the waste management in construction and demolition operations requires a comprehensive approach, the wood fraction can play an important role in achieving high levels of material recovery, especially in Finland and other countries where wood products have been used intensively in buildings. Therefore, the development of specific criteria to take into account the local characteristics of the waste chain should be considered.

The study considers the most commonly used certification schemes in Finland for residential buildings, which are the most representative building types in the Finnish building stock and within existing wooden buildings. However, a broader analysis of certification schemes, including non-residential buildings, could provide a more comprehensive framework on the assessment of wood materials.

\section{References}

Blengini, G.A. \& Di Carlo, T., 2010, "The changing role of life cycle phases, subsystems and materials in the LCA of low energy buildings", Energy and Buildings, vol. 42, no. 6, pp. 869-880.

Brandner, R., Flatscher, G., Ringhofer, A., Schickhofer, G. \& Thiel, A., 2016, "Cross laminated timber (CLT): overview and development", European Journal of Wood and Wood Products, vol. 74, no. 3, pp. 331-351.

BREEAM, 2016. BREEAM International New Construction 2016. Technical Manual SD233. Available through: https://www.breeam.com/discover/technicalstandards/newconstruction/ [Accessed 6th December 2019].

Bribián, I.Z., Capilla, A.V. \& Usón, A.A., 2011, "Life cycle assessment of building materials: Comparative analysis of energy and environmental impacts and evaluation of the eco-efficiency improvement potential", Building and Environment, vol. 46, no. 5, pp. 1133-1140.

Chastas, P., Theodosiou, T. \& Bikas, D., 2016, "Embodied energy in residential buildings-towards the nearly zero energy building: A literature review", Building and Environment, vol. 105, pp. 267-82.

Cobut, A., Beauregard, R. \& Blanchet, P., 2013, "Using life cycle thinking to analyze environmental labeling: the case of appearance wood products", International Journal of Life Cycle Assessment, vol. 18, pp. 722-742.

Corrado, S. \& Sala, S. Bio-Economy Contribution to Circular Economy. In: E. Benetto, K. Gericke and M. Guiton eds. 2018. Designing Sustainable Technologies, Products and Policies: From Science to Innovation. Cham: Springer International Publishing. pp. 49-59. 
Dahlbo, H., Bachér, J., Lähtinen, K., Jouttijärvi, T., Suoheimo, P., Mattila, T., Sironen, S., Myllymaa, T. \& Saramäki, K., 2015, "Construction and demolition waste management - a holistic evaluation of environmental performance", Journal of Cleaner Production, vol. 107, pp. 333-341.

DG ENV European Commission, 2013. Service Contract on Management of Construction and Demolition Waste. SR1 Final Report Task. Available through: https://publications.europa.eu/en/publication-detail/-/publication/0c9ecefc-d07a492e-a7e1-6d355b16dde4 [Accessed 6th December 2019].

Dodge Data \& Analytics, 2018. World Green Building Trends 2018 Smart Market Report. Available through: https://www.worldgbc.org/news-media/worldgreen-building-trends-2018-smartmarket-report-publication [Accessed 6th December 2019].

Dodoo, A., Gustavsson, L. \& Sathre, R., 2009, "Carbon implications of end-oflife management of building materials", Resources, Conservation and Recycling, vol. 53, pp. 276-286.

EN 15978, 2011. Sustainability of construction works - Assessment of environmental performance of buildings - Calculation method. Brussels: European Committee for Standardization.

EN 13986+A1, 2015. Wood-based panels for use in construction Characteristics, evaluation of conformity and marking. Brussels: European Committee for Standardization.

European Commission, 2004. Communication from the Commission - Towards a thematic strategy on the urban environment. COM/2004/0060 final. Brussels.

European Commission, 2017a. Level(s)-A common EU framework of core sustainability indicators for office and residential buildings. Parts 1 and 2: Introduction to Level(s) and how it works. Available through:

https://ec.europa.eu/environment/eussd/buildings.htm [Accessed 6th December 2019].

European Commission, 2017b. Level(s)-A common EU framework of core sustainability indicators for office and residential buildings. Parts $t$ 3: How to make performance assessments using Level(s). Available through:

https://ec.europa.eu/environment/eussd/buildings.htm [Accessed 6th December 2019].

European Commission, n.d. EU Building Stock Observatory. Available through: https://ec.europa.eu/energy/en/topics/energy-efficiency/energy-performance-ofbuildings/eubuildings [Accessed 6th December 2019].

Franzini, F., Toivonen, R. \& Toppinen, A., 2018, "Why Not Wood? Benefits and Barriers of Wood as a Multistory Construction Material: Perceptions of Municipal Civil Servants from Finland", Buildings, vol. 8, no. 11:159, pp. 1-15.

Gerilla, G.P., Teknomo, K. \& Hokao, K., 2007, "An environmental assessment of wood and steel reinforced concrete housing construction", Building and Environment, vol. 42, no. 7, pp. 2778-2784.

Gorgolewski, M., 2018. Resource Salvation: The Architecture of Reuse. Oxford: John Wiley \& Sons.

Gustavsson, L., Pingoud, K. \& Sathre, R., 2006, "CO 2 balance of wood substitution: comparing concrete- and wood-framed buildings", Mitigation and Adaptation Strategies for Global Change, vol. 11, no. 3, pp. 667-691.

Hakkarainen, J., Linkosalmi, L., Huovinen, A., Vares, S., Häkkinen, T. \& Veikkola, M., 2019. LVL Handbook. Helsinki: Federation of the Finnish Woodworking Industries.

Karimpour, M., Belusko, M., Xing, K. \& Bruno, F., 2014, "Minimising the life cycle energy of buildings: Review and analysis", Building and Environment, vol. 73, pp. 106-14. 
Kovacic, I., Reisinger, J. \& Honic, M., 2018, "Life Cycle Assessment of embodied and operational energy for a passive housing block in Austria", Renewable and Sustainable Energy Reviews, vol. 82, no. 2, pp. 1774-1786.

Laaksonen, J., Merilehto, K., Pietarinen, A. \& Salmenperä, H., 2017. National Waste Plan to 2023. Background report (in Finnish: Jätesuunnitelma vuoteen 2023. Taustaraportti). Helsinki: Ministry of the Environment.

LEED, 2013. LEED v4 for Homes Design and Construction. Available through: https://new.usgbc.org/guide/homes\#rating [Accessed 6th December 2019].

Leskinen, P., Cardellini, G., González-García, S., Hurmekoski, E., Sathre, R., Seppälä, J., Smyth, C., Stern, T. \& Verkerk, P.J., 2018. Substitution effects of wood-based products in climate change mitigation. From Science to Policy 7. European Forest Institute. Available through: https://www.efi.int [Accessed 6th December 2019].

Li, Q., Long, R., Chen, H., Chen, F. \& Wang, J., 2020, "Visualized analysis of global green buildings: Development, barriers and future directions", Journal of Cleaner Production, vol. 245, n. 118775, pp. 1-15.

Li, Y., Chen, X., Wang, X., Xu, Y. \& Chen, P.-H., 2017, "A review of studies on green building assessment methods by comparative analysis", Energy and Buildings, vol. 146, pp. 152-159.

Nässén, J., Hedenus, F., Karlsson, S. \& Holmberg, J., 2012, "Concrete vs. wood in buildings. An energy system approach", Building and Environment, vol. 51, pp. 361-369.

Nordic Swan Ecolabel, 2016. Nordic Ecolabelling for Small houses, apartment buildings and buildings for schools and pre-schools. Version 3.8. Available through: http://www.nordic-ecolabel.org/product-

groups/group/?productGroupCode=089 [Accessed 6th December 2019].

Official Statistics of Finland, 2018a. Buildings and free-time residences [epublication], Building stock 2017. Helsinki: Statistics Finland. Available through: https://www.stat.fi/til/rakke/2017/rakke_2017_2018-05-25_kat_002_en.html [Accessed 6th December 2019].

Official Statistics of Finland, 2018b. Building and dwelling production [epublication]. Helsinki: Statistics Finland. Available through: https://www.stat.fi/til/ras/index_en.html [Accessed 6th December 2019].

Official Statistics of Finland, 2018c. Buildings and free-time residences [epublication], Appendix table 4. Number of buildings by construction material 1960-2017. Helsinki: Statistics Finland. Available through:

http://www.stat.fi/til/rakke/2017/rakke_2017_2018-05-25_tau_004_en.html [Accessed 6th December 2019].

Pajula, T., Behm, K., Vatanen, S. \& Saarivuori, E. Managing the Life Cycle to Reduce Environmental Impacts. In: S.N. Grösser, A. Reyes-Lecuona, G. Granholm eds. 2017. Dynamics of Long-Life Assets. Cham: Springer International Publishing. pp. 93-113.

Peñaloza, D., Erlandsson, M. \& Falk, A., 2016, "Exploring the climate impact effects of increased use of bio-based materials in buildings", Construction and Building Materials, vol. 125, pp. 219-226.

Pittau, F., Krause, F., Lumia, G. \& Habert, G., 2018, "Fast-growing bio-based materials as an opportunity for storing carbon in exterior walls", Building and Environment, vol. 129, pp. 117-129.

Porumb, V.-A., Maier, G. \& Anghel, I., 2020, "The impact of building location on green certification price premiums: Evidence from three European countries", Journal of Cleaner Production, vol. 272, no. 122080, pp. 1-11.

Puuinfo, 2018a. Finnish planned and under construction wooden block apartment projects, 11/2018. Available through: 
https://www.puuinfo.fi/sites/default/files/Puukerrostalohankekanta\%2C\%20p\%C 3\%A4ivitetty\%2011-2018.pdf [Accessed 6th December 2019].

Puuinfo, 2018b. The role and potential of wood construction in Finland. Available through:

https://www.puuinfo.fi/puutieto/puurakentaminen/puurakentamisen-asema-jamahdollisuudet-suomessa [Accessed 6th December 2019].

Ramage, M.H., Burridge, H., Busse-Wicher, M., Fereday, G., Reynolds, T., Shah, D.U., Wu, G., Yu, L., Fleming, P., Densley-Tingley, D., Allwood, J., Dupree, P., Linden, P.F. \& Scherman, O., 2017, "The wood from the trees: The use of timber in construction", Renewable and Sustainable Energy Reviews, vol. 68, pp. 333-359.

Salmenperä, H., Moliis, K. \& Nevala, S.-M., 2015. Forecasting waste volumes to 2030 - focusing on municipal waste and reaching recycling targets (in Finnish: Jätemäärien ennakointi vuoteen 2030 - Painopisteenä yhdyskuntajätteet ja kierrätystavoitteiden saavuttaminen). Helsinki: Ministry of the Environment.

Saraiva Freitas, I. A. \& Zhang, X., 2018, "Green building rating systems in Swedish market - A comparative analysis between LEED, BREEAM SE, GreenBuilding and Miljöbyggnad", Energy Procedia, vol. 153, pp. 402-407.

Sartori, I. \& Hestnes, A.G., 2007, "Energy use in the life cycle of conventional and low-energy buildings: A review article", Energy and Buildings, vol. 39, pp. 249-57.

Säynäjoki, E., Heinonen, J., Rantsi, J. \& Junnila, S., 2012. Improving ecoefficiency of the built environment - tools for local action. In: Joint CIB W070, W092 and TG72 International Conference. Cape Town, South Africa, 23-25 January 2012, pp. 396-402.

Schauerte, T., 2010. Wooden house construction in Scandinavia - a model for Europe. In: Internationales Holzbau-Forum (IHF 2010). Garmisch, Germany, 13 December 2010, pp. 1-10.

Sunabacka S., 2015. Strategic Programme for the Forest Sector reached its targets. Helsinki: Ministry of Economic Affairs and Employment.

Suzer, O., 2019, "Analyzing the compliance and correlation of LEED and BREEAM by conducting a criteria-based comparative analysis and evaluating dual-certified projects", Building and Environment, vol. 147, pp. 158-170.

Takano, A., Hughes, M. \& Winter, S., 2014, "A multidisciplinary approach to sustainable building material selection: A case study in a Finnish context", Building and Environment, vol. 82, pp. 526-535.

Tettey, U.Y.A., Dodoo, A. \& Gustavsson, L., 2014, "Effects of different insulation materials on primary energy and $\mathrm{CO}_{2}$ emission of a multi-storey residential building", Energy and Buildings, vol. 82, pp. 369-377.

UN Environment and International Energy Agency, 2017. Towards a zeroemission, efficient, and resilient buildings and construction sector. Global Status Report 2017. Available through:

https://www.worldgbc.org/sites/default/files/UNEP\%20188_GABC_en\%20\%28w eb\%29.pdf [Accessed 6th December 2019].

Upton, B., Miner, R., Spinney, M. \& Heath, L.S., 2008, "The greenhouse gas and energy impacts of using wood instead of alternatives in residential construction in the United States", Biomass and Bioenergy, vol. 32, pp. 1-10.

Zubizarret, M., Cuadrado, J., Orbea, A. \& García, H., 2019, "Modeling the environmental sustainability of timber structures: A case study", Environmental Impact Assessment Review, vol. 78, n. 106286, pp. 1-11. 